\title{
Effect of foliar spraying with atonic on some vegetative and flowering characteristics of cucumber Cucumis melo. Var flexuosus
}

\author{
${ }^{1}$ Ghufran Zaid Khalaf AL-Rikabi, ${ }^{2}$ Batool Hanoon Falih AL-Zubaidy \\ ${ }^{12}$ Department of Horticulture and Landscape Engineering - College of Agriculture and Marshes - Dhi Qar University \\ ${ }^{2}$ Email:batool-z@utq.edu.iq
}

\begin{abstract}
:
The experiment was carried out in one of the unheated greenhouses in the station of the College of Agriculture and Marshes / University of Dhi Qar during the fall season 2020-2021, to study the effect of the atonic biostimulant on the growth and yield of cucumber (Cucumber.(Cucumis melo. Var flexuosus naud (Under protected cultivation, and used two types of cucumber plant (al - Baghdadi and Hillawi), and implemented using the design of full random sectors included working experience and three replicates a compatibility between the two types of Alqthae option and four concentrations of the catalyst vital Alatunak were compared to the average transaction under test less significant difference Significant Differences Least LSD at a probability level of 0.05 .
\end{abstract}

The results can be summarized as follows:

1- Al-Baghdadi cultivar was significantly superior to Al-Halawi cultivar in most of the traits (plant height, stem diameter, number of leaves, number of branches and percentage of fruit set), which reached ( 225.0 Plant $\mathrm{cm}^{-}$ ${ }^{1}$ and1.383 Plant $\mathrm{cm}^{1-}$ and246.2 leaf and 11.40plant branch and65.15\%) sequentially.

2- The addition of atonic spray treatment at a concentration of $1.5 \mathrm{ml} \mathrm{L}^{1-}$ significantly affected the vegetative characteristics, as it gave the highest rates (plant height, stem diameter, number of leaves, number of branches and percentage of fruit set) which recorded $\left(252.5 \mathrm{~cm}\right.$ plant ${ }^{1-}$ and1.667 Plant $\mathrm{cm}^{1-}$ and 250.8 leaves ${ }^{1-}$ and13.25plant branch and\% 81.60 ( sequentially, either the comparison treatment gave the lowest rates .

3- As for the interaction treatments, the treatment of Al-Baghdadi cultivar was superior to that of foliar spraying with atonic stimulator at a concentration of $1.5 \mathrm{ml} \mathrm{L}^{1-}$ in all traits (plant height, stem diameter, number of leaves, number of branches and percentage of fruit set) which reached $\left(256.0 \mathrm{~cm}\right.$ plant ${ }^{1-}$ and $1.733 \mathrm{Plant} \mathrm{cm}^{1-}$ and 278.3 leaf ${ }^{1-}$ and 14.00 Plant branch ${ }^{1-}$ and 87.75 (\%sequentially, either the comparison treatment gave the lowest rates.

Keywords: Cucumber, atonics, fruit set, plant height 


\section{INTRODUCTION}

Cucumber is a cucumber Cucumis melo. Var flexuosus naud It is one of the important summer vegetable crops in Iraq and the world, and it belongs to the Qara family Cucurbitaceae It is believed that the Mediterranean basin is its original home (15), it is cultivated for the purpose of obtaining its fruits that contain vitamin) A,B,C (In addition to calcium, phosphorus, iron, elemental sulfur and manganese, which is a strong chilled taste where eaten fresh fruit or used in pickles and authorities, as well as it is almost like watermelon plant, except for disagreeing nature of the flowers is a single sex and single dwelling, grown cucumbers option in Iraq In the open fields with two loops (spring and autumn), it can also be grown under plastic tunnels and greenhouses (15). It is considered a moisturizing plant, a blood cleanser, a solvent for urinary acids and its salts are diuretics. It is used to treat freckles and melasma, where the face can be washed with it, and it has different names, including: Al-Tarouzi, Al-Tarouzi. Carcass cucumbers, serioui, serbouli and saburi, and when their fruits are left to the stage of full maturity, they will be thick and large in size, white or yellow, with a taste of watermelon, and with different flavors, including sweet, acidic, and dull in taste... It is called shilluk locally. It is noted that the productivity of cucumbers is relatively low in the country and that increasing the level of productivity can be achieved by studying the environmental conditions that affect the growth and yield of the plant, especially the fertilization factor, which is one of the important factors due to its clear impact on improving the growth of plants and its yield. Recently, the use of modern agricultural methods that seek to improve the growth of plants and to produce safe and high-quality food in a manner that protects the environment, including the use of bio-stimulants, and these stimuli are the use of atonic bio-stimulant, which has proven its efficiency in improving the growth and productivity of various horticultural plants, because of the advantages that this bio-stimulator has, especially In the case of exposure to stress factors that negatively affect the growth and productivity of the plant, and because it increases the ability of plants to absorb nutrients, it is preferable to apply the tonic and spray it on horticultural plants to increase their absorption by the plant, and because it contains nutrients that are low in movement and movement in the plant and its great importance in the activities of the plant Vitality is what called for the use of atonics to provide the plant's requirements of it that the roots are unable to provide, as well as the nature of the soil In the southern regions planted with vegetable plants that suffer from a decrease in the readiness of the elements (Al-Sahhaf,; Gadomska and Wierzbicka, 2013; 19892014 ( Przybysz et al ., And due to the lack of research in this field on cucumber, it was decided to conduct this experiment.

\section{MATERIALS AND METHODS}

The experiment was carried out in the greenhouses at the research station / College of Agriculture and the Marshes - University of Dhi Qar within Al-Mustafawiya area in the city of Nasiriyah during the growing season 20202021, where two varieties of cucumber were selected (Halawi and Baghdadi), for the purpose of studying the effect of foliar spraying with atonic on some vegetative traits For two varieties of cucumber (Baghdadi and Halawi.( Studied traits: 
1- Plant height ( plant-1 cm )

The height of the plants was measured using the metric tape, starting from the place where the stem contacts the soil surface to the growing top of the plant.

2- The diameter of the stem ( plant-1 cm)

The diameter of the leg was measured using the foot Vernier At a height of $1 \mathrm{~cm}$ from the point of contact of the main stem of the plant with the soil of the selected plants and according to its rate.

3- Number of leaves ( leaf-1).

The number of total leaves at the end of the season was calculated for each of the selected plants and then according to their average .

4- the number of branches ( plant branch ${ }^{-1}$ )

The number of branches was measured for 10 plants randomly selected from each experimental unit, by measuring the number of lateral branches on the main stem of each plant and just as their average.

5- Percentage of fruit set. $(\%)$

This trait was calculated on the basis of the number of planted fruits of ten plants selected randomly from each experimental unit to the total number of flowers of the same plants, according to the following equation:

\section{The number of knotted fruits}

Percentage of fruit set $=(\%)----------------------x 100$

The total number of flowers

\section{III.RESULTS AND DISCUSSION}

\section{1-Plant Height (Plant-1 cm)}

The table showed the results of (1) the effect of spraying Balatunak cultivar at the height of the plant Alqthae option (cm plant -1$)$ cultivar Baghdadi was significantly compared to the variety Halawi, where record high of ((225.0 cm -1 plant compared to $(218.2) \mathrm{cm}-1$ plant cultivar Halawy. The same table also shows that the tonic spray treatment had a significant effect, as the two concentrations exceeded $1.5 \mathrm{ml} \mathrm{L}-1$ significantly compared to the control treatment ,which recorded (252.5 and 192.2) $\mathrm{cm}$ plant-1 respectively. While the interaction between the study factors had a significant effect, as the combination between the cultivar and spraying with a tonic had a significant effect, as the Baghdadi variety gave the highest rate of plant height, reaching (256.0) $\mathrm{cm}$ plant-1 at a concentration of $1.5 \mathrm{ml} \mathrm{L-1}$, while the treatment gave The comparison for Halawi cultivar had the lowest average plant height of (190.3) cm plant-1 . 
Table (1) Effect of spraying atonics and cultivar on height of cucumber plant (plant $\mathrm{cm}-1$ )

average class

218.2

\section{Atonic $\mathrm{ml} \mathrm{liter}{ }^{1-}$}

$\begin{array}{llll}1.5 & 1 & 0.5 & 0\end{array}$

$256.0 \quad 232.7 \quad 217.3 \quad 194.0$

$212.3 \quad 190.3$

halawi

$249.0 \quad 221.3$

average atonic

\section{$252.5 \quad 227.0 \quad 214.8 \quad 192$. \\ $252.5 \quad 227.0 \quad 214.8 \quad 192.2$}

\section{Interference of class and} ATonic

13.110

item

LSD

$0.05 \leq$

\section{2- The diameter of the stem (plant $\mathrm{cm} .^{1-}$ )}

The table shows the results of (2) the effect of spraying Balatunak cultivar in the stem diameter of the plant Alqthae option ) cm plant ( ${ }^{1-}$ cultivar Baghdadi was significantly compared Halawi cultivar, where he scored the highest Qatar 1.383 ) ) plant $\mathrm{cm}^{1-}$ compared to (1.325 ${ }^{1-}$ plant $\mathrm{cm}$ per cultivar Halawy. The results of the same table also indicate that the spraying with atonic treatment had a significant effect, as the concentration of $1.5 \mathrm{ml} \mathrm{l}^{-}$ ${ }^{1}$ significantly exceeded compared to the control treatment, which recorded ) 1.667 And1.050 (plant $\mathrm{cm}^{1-}$ sequentially. The interaction between the study factors had a significant effect, as the combination between the cultivar and spraying with a tonic had a significant effect as it gave the Baghdadi variety. The highest rate of leg diameter reached) 1.733)Plant $\mathrm{cm}^{1-}$ at a concentration of $1.5 \mathrm{ml} \mathrm{L},{ }^{1-}$ while the comparison treatment of Halawi cultivar gave the lowest average stem diameter reached ) 1.033 (plant $\mathrm{cm} .{ }^{1-}$

Table(2 Effect of spraying atonics and cultivar on stem diameter of cucumber (plant ${ }^{1} \mathrm{~cm}$ plant)

\begin{tabular}{|c|c|c|c|c|c|}
\hline \multirow{2}{*}{ average class } & \multicolumn{4}{|c|}{ Atonic ml liter ${ }^{1-}$} & \multirow{2}{*}{ item } \\
\cline { 2 - 6 } & 1.5 & 1 & 0.5 & 0 & \\
\hline 1.383 & 1.733 & 1.467 & 1.267 & 1.067 & Baghdadi \\
\hline 1.325 & 1.600 & 1.400 & 1.267 & 1.033 & halawi \\
\hline
\end{tabular}




\begin{tabular}{|c|c|c|c|c|c|}
\hline & 1.667 & 1.433 & 1.267 & 1.050 & average atonic \\
\hline $\begin{array}{c}\text { Interference of class and } \\
\text { ATonic }\end{array}$ & \multicolumn{2}{|c|}{ ATonic } & \multicolumn{2}{|c|}{ item } & \multirow[t]{2}{*}{$\begin{array}{c}\text { LSD } \\
0.05 \leq\end{array}$} \\
\hline 0.174 & \multicolumn{2}{|c|}{0.123} & \multicolumn{2}{|c|}{0.051} & \\
\hline
\end{tabular}

\section{3- Number of leaves}

The results of the table (3) the effect of spraying Balatunak cultivar in the number of leaves of the plant cucumber cucumber) leaf plant ( ${ }^{1-}$ cultivar Baghdadi was significantly compared Halawi cultivar, with an average number of leaves 246.2 ) )Leaf ${ }^{1-}$ compared to ( 197.6 (Leaf ${ }^{1-}$ cultivar Halawy. The same table also shows that the atonic spray treatment had a significant effect, as the concentration of $1.5 \mathrm{ml} \mathrm{L}^{1-}$ significantly exceeded compared to the control treatment ,which recorded (250.8 and 179.7) leaf ${ }^{1-}$ respectively. While the interaction between the study factors had a significant effect, as the combination between the cultivar and spraying with a tonic had a significant effect as it gave the Baghdadi variety. The highest average number of leaves was $(278.3)$ leaf ${ }^{1-}$ at a concentration of $1.5 \mathrm{ml} \mathrm{L},{ }^{1-}$ while the comparison treatment of Halawi cultivar gave the lowest average number of leaves was (156.0) leaf . ${ }^{1-}$

Table (5) the effect of spraying Balatunak cultivar in the number of leaves of the plant cucumber cucumber ( leaf plant.$^{1-}$ )

\begin{tabular}{|c|c|c|c|c|c|}
\hline \multirow[t]{2}{*}{ average class } & \multicolumn{4}{|c|}{ Atonic concentration $\mathrm{ml}^{\cdot{ }^{1-}}$ liter } & \multirow[t]{2}{*}{ class effect } \\
\hline & 1.5 & 1 & 0.5 & 0 & \\
\hline 246.2 & 278.3 & 257.3 & 245.7 & 203.3 & Baghdadi \\
\hline 197.6 & 223.3 & 210.0 & 201.0 & 156.0 & halawi \\
\hline & 250.8 & 233.7 & 223.3 & 179.7 & average atonic \\
\hline $\begin{array}{c}\text { Interference of class and } \\
\text { ATonic }\end{array}$ & \multicolumn{2}{|c|}{ ATonic } & \multicolumn{2}{|c|}{ item } & $\begin{array}{c}\text { LSD } \\
0.05 \leq\end{array}$ \\
\hline 12.920 & \multicolumn{2}{|c|}{9.140} & \multicolumn{2}{|c|}{6.460} & \\
\hline
\end{tabular}

\section{4- Number of branches (plant branch. ${ }^{1-}$ )}

Table results show) 4The effect of spraying with Atonik and the cultivar on the number of branches of the cucumber plant) plant branch $\left({ }^{1-}\right.$ The Baghdadi cultivar significantly outperformed the Halawi cultivar in the average number of branches, which recorded the highest average number of branches 12.33 ) )Nata Branch ${ }^{1-}$ compared to ( 11.40 (plant branch $^{1-}$ of the cultivar Halawy. The same table also shows that the treatment of spraying with tonic had a significant effect, as the concentration of $1.5 \mathrm{ml}^{1-}$ significantly exceeded compared to the control treatment, which recorded )13.25And 10.83 (plant branch ${ }^{1-}$ sequentially. 
While the interaction between the study factors had a significant effect, as the combination between the cultivar and spraying with tonic had a significant effect, as the Baghdadi variety gave the highest average number of branches,

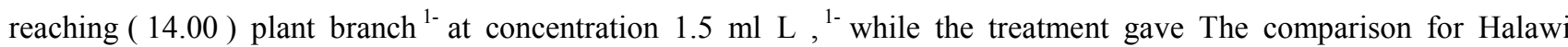
cultivar had the lowest average number of branches reached ) 10.00Plant branch. ${ }^{1-}$

Table (4) Effect of spraying with Atonik and cultivar on the number of shoots of Cucumber Cucumber (Plant Branch. ${ }^{1-}$ )

\begin{tabular}{|c|c|c|c|c|c|}
\hline \multirow{2}{*}{ average class } & \multicolumn{4}{|c|}{ Atonic $\mathrm{ml}$ liter ${ }^{1-}$} & \multirow[t]{2}{*}{ item } \\
\hline & 1.5 & 1 & 0.5 & 0 & \\
\hline 12.33 & 14.00 & 12.33 & 11.33 & 11.66 & Baghdadi \\
\hline \multirow[t]{2}{*}{11.40} & 12.50 & 11.90 & 11.20 & 10.00 & halawi \\
\hline & 13.25 & 12.11 & 11.26 & 10.83 & average atonic \\
\hline $\begin{array}{c}\text { Interference of class and } \\
\text { ATonic }\end{array}$ & \multicolumn{2}{|c|}{ ATonic } & \multicolumn{2}{|c|}{ item } & LSD \\
\hline 0.776 & \multicolumn{2}{|c|}{0.548} & \multicolumn{2}{|c|}{0.388} & $0.05 \leq$ \\
\hline
\end{tabular}

5- Percentage of fruit set.(\%)

The results of Table (5) showed the effect of spraying with Atonik and the variety on The percentage of fruit set (\%) of cucumber plants was significantly superior to the Baghdadi variety compared to the cultivar Halawi, where the highest average percentage of fruit set was recorded .65.15) \%)compared to(59.59\% (for class Halawy. The same table also shows that the treatment of spraying with tonic had a significant effect, as the concentration of $1.5 \mathrm{ml} \mathrm{l}^{-}$ ${ }^{1}$ significantly exceeded compared to the control treatment, which recorded ) 81.60And50.56\% (sequentially. While the interaction between the study factors had a significant effect, as the combination between the cultivar and spraying with a tonic had a significant effect as it gave the Baghdadi variety. The highest percentage rate for fruit setting reached )87.75\%)at a concentration of $1.5 \mathrm{ml} \mathrm{L},{ }^{1-}$ while the comparison treatment for Halawi cultivar gave the lowest percentage of fruit set percentage that reached $(49.18 \%)$.

Table (5) Effect of spraying with atonics and the variety on Fruit set percentage (\%) of cucumber plants.

\begin{tabular}{|c|c|c|c|c|c|}
\hline \multirow{2}{*}{ average class } & \multicolumn{4}{|c|}{ Atonic ml liter ${ }^{1-}$} & \multirow{2}{*}{ item } \\
\cline { 2 - 5 } & 1.5 & 1 & 0.5 & 0 & \\
\hline 65.15 & 87.75 & 68.51 & 52.40 & 51.95 & Baghdadi \\
\hline 59.59 & 75.45 & 49.96 & 63.75 & 49.18 & halawi \\
\hline
\end{tabular}




\begin{tabular}{|c|c|c|c|c|c|}
\hline & 81.60 & 59.23 & 58.08 & 50.56 & average atonic \\
\hline $\begin{array}{c}\text { Interference of class and } \\
\text { ATonic }\end{array}$ & \multicolumn{2}{|c|}{ ATonic } & item & LSD \\
\cline { 1 - 2 } 16.720 & 9.820 & $3.05 \leq$ \\
\hline
\end{tabular}

The results showed that the effect of the cultivar and the concentrations of the atonic foliar spray treatment and their interactions had a significant effect on plant height, stem diameter, number of leaves, number of branches and percentage of fruit set. The hybrids differed among themselves in schedules 2,1 and3 And 4 (5 The reason is due to the genetic factors of the hybrid and their response to environmental factors.This agrees with what I found.(2002)The reason for the increase in the height of the plant, the diameter of the stem, the number of leaves and the number of branches is attributed to the treatment with atonic biostimulator because it contains nitrogen, which works on cell division, which leads to increased root growth. Within plant tissues, the results agree with Wajda ( Djanaguiraman et al., 2005)The reason for the increase in plant height, stem diameter, number of leaves and number of branches is also attributed to the role of the biostimulant atonic in the withdrawal of nutrients, as well as their role in stimulating the division and elongation of cells and their development by increasing their content of auxins. High, which is positively reflected in the increase in plant height and stem diameter( Djanaguiraman et al ., 2005b; Arora and Singh, 1972) ; Haroun et al. 2011 )The reason for the increase in the percentage of fruit set is attributed to the addition of atonic to its high content of auxin, which prevents the emergence of male flowers and causes the appearance of female flowers (Al- Juboory et al ., 1990) .It is known that treatment with auxins stimulates the formation of ethylene in the plant(Fuchs and Lieberman, 1968)This ethylene, in turn, maintains the decomposition of auxin and inhibits its movement in the plant(Beyer and Morgan, 1969)Thus ,auxin accumulates and its level increases in the plant, thus causing an increase in the number of female flowers, and this is reflected positively in increasing the process of setting fruits.

\section{References}

[1] Al-Mathoub, Adnan Nasser, Izz al-Din Sultan Muhammad, and Karim Saleh Abdoul. 1989. They studied vegetables, part two, Higher Education Press, Mosul University, 337 p.

[2] Al-Saeedi, Hussein Lafta 2017. Effect of spraying with atonic and boron on some physical, chemical and physiological characteristics of leaves and fruits of Sidr trees. Master Thesis _ College of Agriculture _ University of Basra _ Iraq.

[3] Al-Sahhaf, Fadel Hussein (1989). Applied plant nutrition. Ministry of Higher Education and Scientific Research, House of Wisdom, University of Baghdad, Iraq: 97-104 p. 
[4] Al-Zaidi, Hind Jawad Kazim (2002), Effect of spraying with iron, zinc, boron and gibberellic acid on the growth, yield and quality of sweet pepper (Capsicum annuum L.), Seed Technology Center, Agricultural Research and Food Technology Department, Ministry of Science and Technology, Baghdad-Iraq 2002.

[5] Al-Jubouri, Razak Kazem Rahman (2009). Effect of foliar spraying with some micronutrients, growth regulator (Atonik) and cultivar on growth, yield and some chemical characteristics of tomato grown in unheated greenhouses. Karbala University Scientific Journal, 7(4): 1-13.

[6] A.O.A.C. (1980). Official methods of analysis. 13th ed. Washington, D. C. Association of the Official Analytical Chemist. pp . 910.

[7] Dobois, M K.; K. A. Crilles; J.K. Hamilton ; D.A. Rebers and F. Smith (1956). Colorimetric method for determination of sugars and substances .Anal. Chem., $28: 350-356$.

[8] Goodwin, T.(1976). Chemistry and Biochemistry of Plant pigments. $2^{\text {nd }}$ ed. Academic Press . New York. San Francisco.USA., 373.PP.

[9] Page, A. L.; R.H. Miller and D. R. Keeney (1982). Methods of soil analysis, part2, 2nd Ed. Madison, Wisconson, USA, PP.1159. Premalatha,M.G.S.;Wahundeniya,K.B.;Weerakkody,W.A.P;and.W

[10] Haroun, S. A.; Shukry, W. M.; Abbas, M. A.; and Mowafy, A. M. (2011). Growth and physiological responses of Solanum lycopersicum to atonik and benzyl adenine under vernalized conditions. Journal of Ecology and the Natural Environment, 3(9): 319-331.

[11] Havlin, J. L.; Beaton, J. D.; Tisdale, S. L.; and Nelson W. L. (2005). Soil Fertiity and fertilizers: $7^{\text {th }}$ Ed. An Introduction to Nutrient Management Upper Saddle River, New Jersey. U.S.A

[12] Mazher, A. A. M.; Zaghlol, S. M. and Yassen, A. A. (2006). Impact of boron fertilizer on growth and chemical constituents of Taxodium distichum growth under water regime. World J. Agric. Sci., 2 (4): 412 - 420.

[13] Djanaguiraman, M.; Sheeba, J. A.; devi, D. D. and Bangarusamy, U. (2005). Effect of atonik seed treatment on seedling physiology of cotton and tomato. Journal of Biological Sciences, 5 (2): 163-169.

[14] Bonilla, I.; Cadahia, C.; Carpena, O. and Hernando, V. (1980). Effect of boron on nitrogen metabolism and Sugar levels of sugar beet. Plant and Soil, 57: 3-9.

[15] Dzondo - Gadet, M.; Mayap-Nzietchueng, R.; Hess, K.; Nabet, P.; Belleville, F. and Dousset, B. (2002). Action of boron at the molecular level effects on transcription and translation in a cellular system. J. Biol. Trace Element Res., 85:23-33.

[16] Mikos-Bielak, M. (2004). Bioregulation of yielding and chemical quality of raspberry as an effect due to Asahi. Annals UMCS Sec. E., 59 (3): 1471-1479. 
[17] Trautner, K. and Somogyi, J. C. (1964). Biosynthesis of vitamin-C in potato slices. Intern. Z. Vitamin forsch., 34: $433-435$.

[18] Szot, I.; Lipa, T. and Basak, A. (2014). The influence of atonik sl, betokson super $050 \mathrm{sl}$ and insol ca on yielding of strawberry (fragaria ananassa duch.) cv. 'senga sengana' and 'kent'. Acta Agrobotanica, 67 (2): 9-108.

[19] Blokhina, O.; Virolainen, E. and Fagerstedt, K.V. (2003). Antioxidant oxidative damage and Oxygen deprivations stress. Annals of Botany, 91:179 194.

[20] Jwar, A. S., \& Abdul-Wahid, M. S. (2018). Effect of different pollen grain source and chitosan on some physiological and enzymatic characteristics of data palm Phoenix dactylifera L. fruits cv. Alshwethey. Basrah Journal For Date Palm Research, 17(1-2). 